\author{
D. Mojon \\ D. Boscoboinik \\ A. Haas \\ M. Böhnke \\ A. Azzi
}

\section{Inhibition of bovine RPE cells by vitamin $E$ succinate}

Received: 1 October 1996

Dear editor: We read with great interest the article by Sakamoto et al. [1] reporting an inhibition of proliferation and migration of bovine retinal pigment epithelial (RPE) cells cultured in vitro by vitamin $\mathrm{E}$ succinate. In 1994, we reported a dose-dependent inhibitory effect of vitamin $E$ on human RPE cell proliferation with therapeutic implications for proliferative vitreoretinopathy [2]. Unfortunately, Sakamoto et al. [1] did not cite our article. We found inconsistent inhibition at $25 \mu \mathrm{M}$ vitamin $\mathrm{E}$; more complete inhibition was achieved at $50 \mu \mathrm{M}$ and $100 \mu \mathrm{M}$, doses which can be reached within the eye with oral supplementation. We never observed toxic effects of vitamin $\mathrm{E}$ on human cell cultures, even after 8 days of incubation $[2,3]$.

We did not test the effect of vita min E succinate on human RPE cells since we noticed cytotoxic effects at rather low concentrations. Such a conclusion may be supported by the findings reported by Sakamoto et al. themselves that "after 5 days of incubation in vitamin E succinate $(25 \mu \mathrm{M})$ RPE cells changed shape from epithelioid to round and started to float into the medium" and "cell viability ... was slightly impaired at $100 \mu \mathrm{M}$ after 3 days".

Sakamoto et al. used bovine RPE cell cultures and tested only a dose of $25 \mu \mathrm{M}$ of vitamin $\mathrm{E}$ and found a slight stimulation of cell growth.
This is an unusual finding that might be interpreted as the removal of lipoperoxide-induced inhibition of growth, occurring at later incubation stages.

\section{References}

1. Sakamoto T, Hinton DR, Kimura H, Spee C, Gopalakrishna R, Ryan SJ (1996) Vitamin E succinate inhibits proliferation and migration of retinal pigment epithelial cells in vitro: therapeutic implication for proliferative vitreoretinopathy. Graefe's Arch Clin Exp Ophthalmol 234: 186-192

2. Mojon D, Boscoboinik D, Haas A, Boehnke M, Azzi A (1994) Vitamin E inhibits retinal pigment epithelium cell proliferation in vitro. Ophthalmic Res 26: 304-309

3. Haas A, Boscoboinik D, Mojon D, Bohnke M, Azzi A (1996) Vitamin E inhibits proliferation of human tenon's capsule fibroblasts in vitro. Ophthalmic Res 28: 171-176

D. Mojon (局 · A. Haas · M. Böhnke Institute of Opthalmology,

University of Bern, CH-3010 Berin, Switzerland

D. Boscoboinik · A. Azzi

Institute of Biochemistry and

Molecular Biology, University of Bern,

Bern, Switzerland

\section{T. Sakamoto \\ D.R. Hinton \\ R. Gopalakrishna S.J. Ryan}

\section{Reply}

Received: 13 December 1996

Dear editor: We read with interest the comments by Mojon et al. concerning our recent publication in Graefe's Archive for Clinical and Experimental Ophthalmology [1]. We apologize for not quoting his recent publication [2]; at the time our paper was submitted, his paper had just been published and was not yet in the Medline database.

While our article studied primarily the effects of vitamin $E$ succinate on retinal pigment epithelium (RPE) cell proliferation and migration, Mojon et al. studied the effects of vitamin E on RPE proliferation. They found that vitamine E inhibited RPE proliferation without toxicity at the doses tested. In our own experience and in the experience of others, low doses of $\sigma$ - $\alpha$-tocopherol (vitamin E) do not inhibit cell growth in vitro for RPE cells [1] and a variety of cancer cells [3-6]. Gopalakrishna et al. found in lung cancer cells that only higher doses of vitamin $\mathrm{E}(250 \mu \mathrm{M})$ significantly inhibited thymidine uptake [7]. Some of the differences between our study and that of Mojon et al. may be due to differences in methodology. We perform our studies in $\log$ phase of cell growth while they use cells grown to subconfluency, made quiescent by growth in low serum and then tested in the presence of $10 \%$ serum.

Mojon et al. indicate that they did not test vitamin E succinate on RPE because of toxicity at rather low concentrations. We do not believe that vitamin $E$ succinate causes acute cytotoxicity because the effects on cell survival occur only after 3 days of incubation, suggesting an active process of cell death, possibly apoptosis. In retrovirustransformed cells [8] and human breast cancer cells [9] vitamin E succinate inhibits cell proliferation by a cytostatic mechanism which may be mediated by TGF- $\beta$.

As indicated by Mojon et al., we found that vitamin $E$ stimulated slightly the proliferation of RPE cells, a finding that has been previously reported in vascular endothelial cells [10] and cancer cells [8]. We agree with their speculation that this may be a result of removal of lipid peroxides. 